\title{
The handwriting of society on the landscape: modeling of the Environmental Changes on the Borders of Protected Areas located in the Espinhaço Mountain Range, state of Minas Gerais, Brazil ${ }^{1}$
}

\section{A caligrafia da sociedade na paisagem: modelagem ambiental das transformações ambientais no entorno de Unidades de Conservação da Serra do Espinhaço, Minas Gerais, Brasil}

Ana Pimenta Ribeiro ${ }^{a}$

José Augusto Drummond

Eduardo Magalhães Ribeiro ${ }^{c}$

${ }^{a}$ Doctor, Institut for Environmental Planning - Leibniz Universität Hannover, Hannover, Germany. E-mail: piperaceae@gmail.com

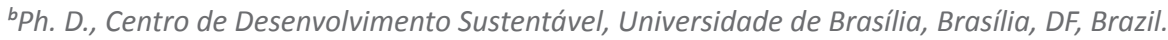
E-mail: jaldrummond@uol.com.br

'Doctor, Instituto de Ciências Agrárias, Universidade Federal de Minas Gerais, Montes Claros, MG, Brazil.

E-mail: eduardoribeiromacuni@gmail.com

doi:10.18472/SustDeb.v11n2.2020.28393

\section{ABSTRACT}

This paper analyzes the contexts of the creation of two protected areas located on the Espinhaço Mountain Range, in the state of Minas Gerais (Brazil): Rio Preto State Park and Serra Negra State Park. It compares the social and natural contexts of the creation process of both protected areas between the years 1986 and 2009. To this end, we sought to understand the patterns of natural resources use by local populations, relating them to the outcomes of land use dynamics over time, identified through monitoring with orbital imagery images and through environmental modeling. Regarding land use analysis, changes in the landscape around the Rio Preto State Park corroborated field surveys, which registered an increase in the local population's perception of environmental problems and in the inspection after the park's creation. No relevant relation was found for the Serra Negra State Park. Environmental modeling of the Rio Preto State Park recorded a positive result in terms of environmental protection, because a trend of natural resource degradation was contained after the park's creation. For the Serra Negra State Park, although protection of the area did not influence landscape changes, the dynamics of resource use by the local population did not degrade the natural environment. 
Keywords: Protected Areas. Land Use Change. Environmental Conflicts. Geoprocessing. Environmental Modeling. Deforestation.

\section{RESUMO}

Este artigo analisa os contextos da criação de duas áreas protegidas localizadas na Serra do Espinhaço, no estado de Minas Gerais (Brasil): Parque Estadual do Rio Preto e Parque Estadual de Serra Negra. O trabalho compara os contextos sociais e naturais do processo de criação das duas áreas protegidas entre os anos de 1986 e 2009. Para tanto, buscamos entender os padrões de uso dos recursos naturais pelas populações locais, relacionando-os com os resultados da dinâmica do uso da terra ao longo do tempo, identificados através do monitoramento com imagens orbitais e através da modelagem ambiental. Quanto à análise do uso do solo, as mudanças na paisagem ao redor do Parque Estadual do Rio Preto corroboraram os levantamentos de campo, que registraram um aumento na percepção da população local sobre os problemas ambientais e na fiscalização após a criação do parque. Nenhuma relação relevante foi encontrada para o Parque Estadual de Serra Negra. A modelagem ambiental do Parque Estadual do Rio Preto registrou um resultado positivo em termos de proteção ambiental, pois uma tendência de degradação dos recursos naturais foi contida após a criação do parque. Para o Parque Estadual de Serra Negra, embora a proteção da área não tenha influenciado as mudanças na paisagem, a dinâmica de uso dos recursos pela população local não degradou o ambiente natural.

Palavras-chave: Áreas Protegidas. Mudança no uso do solo. Conflitos ambientais. Geoprocessamento. Modelagem Ambiental. Desmatamento.

\section{INTRODUCTION}

Interpretations of the ways by which humans relate to the natural environment come from different fields of knowledge, such as anthropology, sociology and geography (KUGLER et al., 2019; MORAN, 2011). These relationships can be studied by field research aimed at understanding local activities in the day-to-day life of communities that use natural resources (GALIZONI, 2000; RIBEIRO et al., 2005). Studies such as Guadilla-Sáez et al. (2020) and Brugger et al. (2016) allow us to understand how local communities use available resources over the span of centuries.

Another way to seek this understanding is by monitoring continuity and change in the soil cover of a defined study area (BRONDíZIO, 2009). Spatial analyses, typically used in biophysical studies, provide important information for social research. Geographic Information Systems (GIS) and Remote Sensing (RS) techniques, applied to surveys about landscape fragmentation, help verify data collected in the field (TUCKER and OSTROM, 2009; YOUNG et al., 2020). Orbital images display portraits of the landscape at a given moment, helping to identify the possibilities of preferred future situations or to improve these possibilities. Kugler et al. (2019) offer an extensive overview of how orbital images help understand interactions between humans and the natural environment, presenting a history of the improvements achieved in this field of research over the last 20 years.

Silva et al. (2016), using sequential analysis, identified the drivers of land use change in remnants of the Brazilian Atlantic Forest in different time periods. Li et al. (2019) used orbital images to examine the dynamics of land use and related it to the dynamics of local social contexts. According to Moran (2011), spatially explicit analyses have caused the greatest revolution in the history of studies about human-environment interactions. The author discusses cases in which landscape analysis over time helps understand cultural narratives, because "human actions carried out in the past leave marks on the current landscape" (Moran, 2011, p. 126).

Using different methodologies, adapted to different environmental realities, can help identify these 'marks on the landscape'. Shimabukuro et al. (2019) present a semi-automatic procedure to monitor deforestation and degradation of the Amazon rainforest. Bicudo da Silva et al. (2017) evaluated land use changes in the Atlantic Forest over a period of almost 30 years. Silveira et al. (2018) developed an 
innovative method of detecting land use change in the Cerrado, a biome that contains a wide range of environments and seasonal changes. The authors use spatial context assessment to eliminate the effects of phenology on classification. Li et al. (2017) propose a system to simulate global land use and cover change (LUCC) regarding human-environment interactions, applying simulations of future uses. These products are important tools that provide information that aids the assessment of impacts and the effectiveness of planning procedures and policies.

Starting from these LUCC analyses - which seek to understand the past or present status of landscapes and seeking to predict future developments, environmental modeling emerges as a new tool. According to Evans et al. (2009), environmental modeling helps forecast alternative scenarios. By simplifying processes, modeling provides the possibility of examining the elements that interact and influence these processes.

The creation of protected areas (PAs) is one of the most frequent measures for conserving nature (Carranza et al., 2014; Heringer et al., 2020; Schulze et al., 2018; Silveira et al., 2018). Devising methods to evaluate their effectiveness generates important sources of data that can be used for making decisions. This efficiency can be evidenced by understanding how neighboring population relate to the PA.

Abukari and Mwalyosi (2018) evaluated how different communities relate to the parks, analyzing what factors, such as knowledge of the park's rules, residents employed in the conservation unit, distance between the communities and the park, and access to non-logging forest products were significant in changing people's attitude in this relationship. Cetas and Yasué (2017) concluded that emphasis on social justice and welfare of the neighboring populations aided the success of biodiversity protection in PAs.

PAs also play an important role in maintaining peoples' connection with the natural environment. According to Cazalis and Prévot (2019), pro-environment behavior decreases with longer distances between communities and parks. In addition to the effect caused by exposure to the natural landscape, the institutional context created by PAs has a strong influence on people's environmental awareness.

In this article we sought to identify land cover changes that occurred between 1986 and 2009 in the state parks of Rio Preto (RPSP) and Serra Negra (SNSP), at intervals that varied between six and eleven years2. This research exercise was conducted (i) to produce a portrait of the landscapes following the creation of both PAs and (ii) to compare it to the landscapes as they were before the PAs, allowing the quantification of land use changes. Additionally, through interviews conducted in the field, we sought to understand the patterns of natural resources use by local populations, relating them to the land use dynamics over time.

We also undertook an environmental modeling analysis, resulting in the identification of landscape use trends before the establishment of the two PAs. By classifying images taken on dates prior to the creation of the PAs, we obtained a model of how the landscape would be in the years 2003 and 2009 if the PAs had not been established. This allowed us to check the effectiveness of the two PAs in conserving the vegetation.

\section{MATERIAL AND METHODS}

\subsection{STUDY AREAS AND INTERVIEWS}

This study was conducted in the southern section of the Espinhaço Mountain Range, in the state of Minas Gerais, Brazil. It focused on two state parks: the Rio Preto (RPSP - created by State Decree \#35.611 of June 1st 1994) and Serra Negra (SNSP, created by State Decree \#39.970 of September 22nd 1998). They are located respectively in the counties of São Gonçalo do Rio Preto and Itamarandiba (Image 1). Both parks were included in a collective management arrangement called "The Conservation Unit Mosaic of Alto do Jequitinhonha - Serra do Cabral", along with 10 other PAs. The study area is located near the headwaters of the Jequitinhonha River, commonly known as Alto Jequitinhonha. 


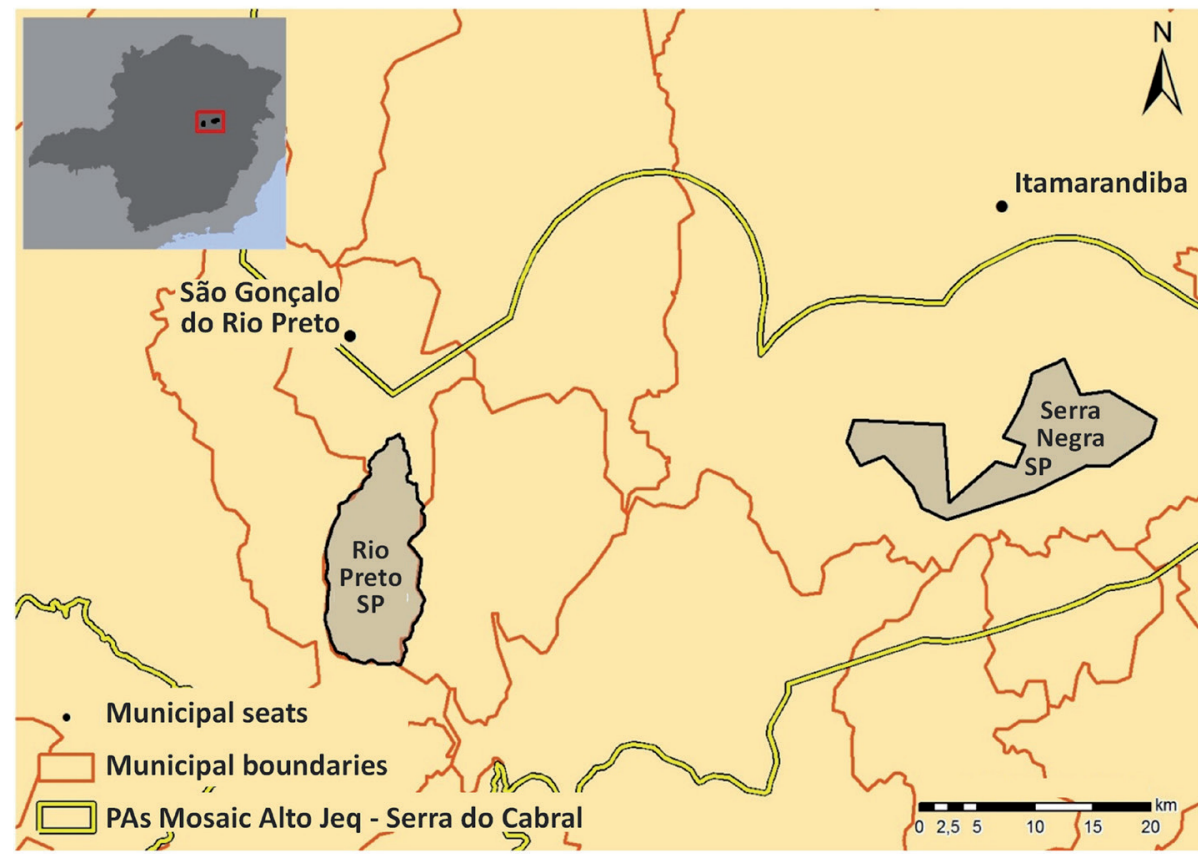

Image 1 | Location of the Rio Preto and Serra Negra State Parks, state of Minas Gerais, Brazil.

Sources: IBGE; IEF; Instituto Biotrópicos, (2013).

Several reasons explain why these two PAs were selected for this study (Ribeiro, 2013). First, they are state units that belong to the same class of PAs; second, their dates of implementation are close to each other (RPSP - 1994; SNSP - 1998); third, both belong to the aforementioned mosaic (established by the Ministry of Environment by Ordinance \#444, of November 26th 2010); fourth, they are inserted in differing institutional contexts. This study found that these institutional differences led the parks to reach different results until 2012 in their common goal of environmental conservation.

To analyze the context of the two PAs, we considered the regional political situation, the Instituto Estadual de Florestas de Minas Gerais (IEF - Minas Gerais State Forestry Institute), and the Secretaria de Estado do Meio Ambiente e Desenvolvimento Sustentável de Minas Gerais (SEMAD - Minas Gerais State Secretariat of the Environment and Sustainable Development). The first round of interviews was conducted between May and June 2012, in Belo Horizonte, the state capital. Interviewees were academics from the UFMG (Federal University of Minas Gerais) engaged in research in the study area; employees of the IEF central office (Department of Protected Areas Creation, Department of Conservation Units, and Regional Coordination of Conservation Units); and employees of the Environment Department of the Agricultural Workers Federation of the state of Minas Gerais (FETAEMG - a workers' union).

A second round of interviews was conducted between July and August 2012 in the municipalities of Diamantina, São Gonçalo do Rio Preto, and Itamarandiba. Interviewees were academics from UFVJM (Federal University of the Valleys of Jequitinhonha and Mucuri) who conduct research in the area; members of the NGO Biotrópicos; IEF employees (management, inspectors, and park rangers of the RPSP; managers of the SNSP; employees of the IEF office in Itamarandiba); the president of the Itamarandiba Rural Workers Union; and farmers from communities located on the borders and inside both PAs.

The purpose of the interviews was to understand the creation processes of the two PAs (motivations, community-park relationships, community organizations) and to identify the institutions that influenced these processes. They also sought to pinpoint the characteristics of the surrounding communities, identify the natural resources used locally, check the makeup of the parks' advisory councils, evaluate the degree of formalization of a proposed biosphere reserve in the study area, evaluate the viability and workings of the mosaic, and examine the impacts of and incentives for regional tourism. We chose to omit the names of the interviewees, clarifying the relevance of each of them in the context of the research. 


\section{LAND USE MONITORING}

To monitor land use in the PAs under analysis, images generated by the Thematic Mapper (TM), based the Landsat 5 platform, were selected and obtained free of charge on the INPE website3, in September 2012. The images are from the years 1986 and 1992, generated between the months of August and October. One scene was selected for each year analyzed. These dates were chosen in order to compare two moments prior to the creation of the studied PAs.

Access to the database called Inventário Florestal da Flora Nativa e dos Reflorestamentos de Minas Gerais ("Forest Inventory of the Native Flora and of the Tree Plantations of the State of Minas Gerais") (Scolforo and Carvalho, 2006) was granted by the IEF, along with the agency's land use classification referring to 2003, 2005, 2007, and 2009. Only data referring to 2003 and 2009 were used in our research, in order to have four different dates with a consistent distribution inside the period of time under study (1986, 1992, 2003, and 2009).

Unsupervised image classification was performed with the aid of the ERDAS Imagine program. This was complemented by the visual adjustment of classes. Forty clusters were defined for our research. Grouping based on spectral similarities resulted in two classes of soil use: native landscapes (NL) and cultural landscapes $(\mathrm{CL})$. Native landscapes, as the term implies, are those not altered by human action. Cultural landscapes encompass the several formations shaped by human actions capable of transforming the natural environment (Corrêa, 1995).

Classifications obtained from the Inventário Florestal... went through a generalization that reduced its original classes to $\mathrm{NL}$ and $\mathrm{CL}$, as well as the images selected for this research. The original classes converted to CL were: eucalyptus, pine, urbanization and "other" - a class than encompasses anthropic uses such as farming areas and roads. According to Lange and Blaschke (2009), although there are few standardized solutions to monitor and analyze changes in land use, they must be based on images generated by the same sensor, they must be selected considering close temporal intervals, and they must adopt the same classification methodology.

Due to the insufficient availability of images, it was not possible to apply the same classification method to all scenes. This limitation was taken into account when analyzing the results and does not affect them or the validity of the methodology. The official data of the aforementioned Inventário Florestal..., although not available for all the years under study, served as a basis for checking classifications for previous years, through visual inspection of the reflectance patterns of each class of the Landsat 5 images corresponding to the classified years. This procedure also ensured the standardization of classifications.

When research was conducted, the RPSP had a management plan indicating its buffer zone; the SNSP did not have such a plan Thus, in order to define the area of analysis around the PAs, a buffer swath with a width of 5 kilometers was defined. This dimension was arbitrated as a conservative estimate based on the CONAMA (National Environment Council) Resolution \# 426, of November 26, 2010, which defines a buffer zone of 3 kilometers wide for PAs lacking a management plan (INSTITUTO CHICO MENDES, 2010). The buffer zone is a swath defined around the borders of PAs in which there are restrictions to human uses and activities, aiming to reduce negative impacts on protected areas (Brasil, 2000).

In the case of the SNSP, the polygon generated by the arbitrated buffer zone touched small portions of the municipalities of Rio Vermelho, Coluna, and Frei Lagonegro. Adjustments were made so that the area under analysis was limited to the municipality of Itamarandiba, because it was found in the field that the three other neighboring municipalities, despite being close to the park, are not influenced by its situation (Image 2). 

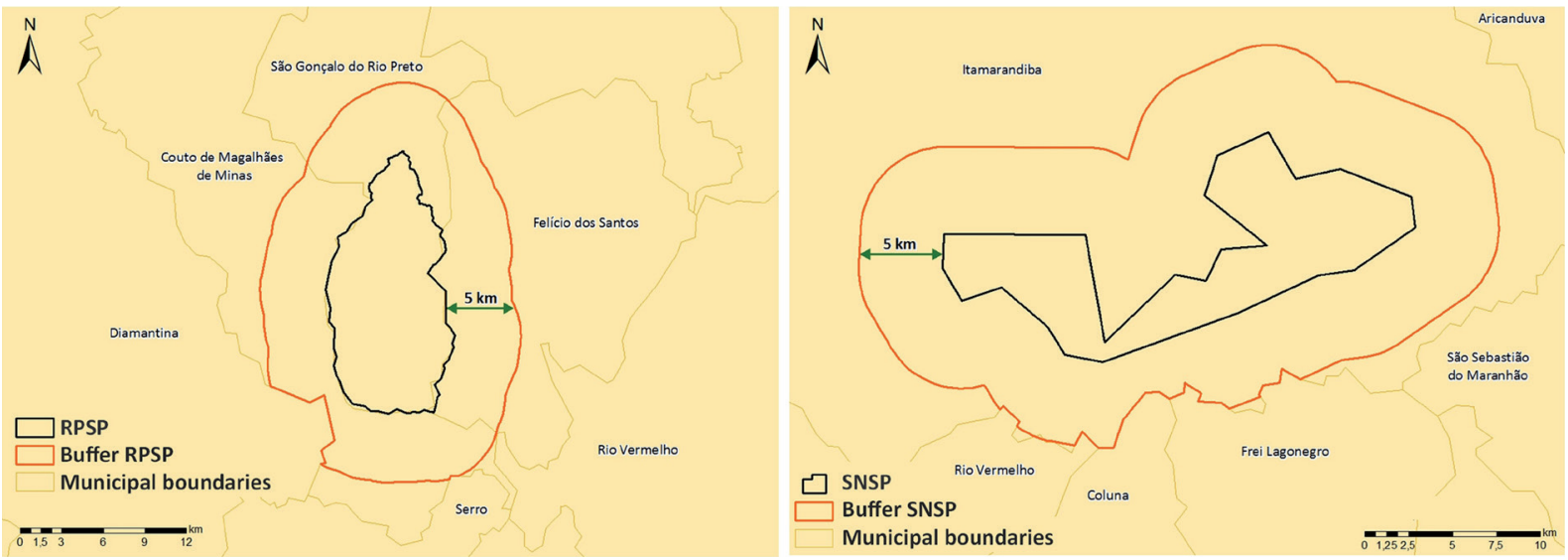

Image 2 | Rio Preto and Serra Negro State Parks, including demarcated areas and buffer zones.

Source: IBGE, IEF (2013).

In the case of the RPSP, the buffer zone reached the municipalities of Diamantina and Serro, not included in the park's management plan as part of its area of influence. In order to avoid including areas not relevant to the analysis, the polygon was also corrected to affect only the municipalities of São Gonçalo do Rio Preto, Couto de Magalhães de Minas and Felício dos Santos (Image 2). The areas analyzed for each park were 41,293 hectares (RPSP) and 54,384 hectares (SNSP). All processing considered these polygons as the areas to be analyzed in each park.

To quantify land use changes, the chosen tool was the extension of the ArcGis program called LUCAT (Land-Use Change Analysis Tools), developed by the Laboratório de Hidrologia Florestal (Laboratory of Forest Hidrology) of the Department of Forest Science, linked to the Luiz de Queiroz School of Agriculture. ${ }^{1}$ This tool makes it easy to measure the proportion and the amount of each use class in the landscape. These measurements make it possible to automatically obtain the variation of each class of landscape use in a given period of time (Ferraz et al., 2009). Soil use changes were analyzed for the intervals 1986 - 1992, $1992-2003$, and 2003 - 2009.

\section{LAND USE TRENDS}

To identify trends in land use, the chosen software was IDRISI Selva (EASTMAN, 2012) and its land use change modeling module called Land Change Modeler (LCM). The purpose was to obtain a scenario in which the PAs did not exist, in order to check if there is a measurable effectiveness of the PAs' conservation goals.

In the model adopted here, the variables selected to explain land use change were (i) proximity among deforestation activities between 1986 and 1992, (ii) terrain slopes, (iii) trends in land use changes between 1986 and 1992, and (iv) terrain elevation. These variables had their explanatory powers ${ }^{2}$ tested by a specific tool within LCM before selection, aiming to check the weight of their correlation with the causes of soil use change. Results reached a 70\% accuracy rate, i.e., the model correctly predicted future soil use in $70 \%$ of the area under analysis.

In order to validate the model generated by the LCM, a new classification was made in reference to a date subsequent to the creation of the parks. The chosen images were generated in 1994 and were interpreted based on Landsat 5 TM images, following the same methodology used in the images for 1986 and 1992.

Modeling was done initially for 1994. The result was compared to the 1994 classification, in order to check the validity of the model. A null model was also generated, in which land uses in 1994 and 1992 were compared. The purpose of this analysis was to check if the model generated by LCM predicted 
the vegetation cover of 1994 more accurately than the comparison with the vegetation cover of 1992. In other words: could the model understand how the landscape would be in 1994? Or, would the percentage of correctness be higher, considering that there has been no change since 1992 (stationary model)?

\section{RESULTS AND DISCUSSION}

\subsection{INTERVIEWS}

Municipalities that contain the studied PAs originated from mining activities, which historically shaped the occupation of the region. São Gonçalo do Rio Preto was founded around 1820, when a small village formed around the church, on the banks of the Preto River (SEMAD, 2004). Itamarandiba, formerly São João Batista, is older: It was founded by colonizers in the 17th century (Prefeitura Municipal de Itamarandiba, 2012).

The RPSP was created in the 1980s, as a consequence of the convergence the local population's interests in protecting natural resources, on the one hand, and the priorities of the state agency in charge of the area's conservation, on the other. Interviewees informed that local communities supported the creation of the park, that a management plan was being drafted, and that the local population participated in planning events.

In the case of the SNSP, little information is available from printed sources. All information presented herein was collected in the field. Ever since its creation, in 1998, the park's management had to deal with the controversial issue of establishing its limits. In 2012, about 160 families were still residing in inside the park. Lack of land tenure titles and lack of government resources to compensate families slated for removal created a conflict between land owners and squatters, on the one side, and park managers on the other (ALMG, 2010).

In addition to the different manners by which the proposals of each park reached the environmental agency and to the different implementation procedures, there was a clear contrast between one area with arable land and another area with poor soils, used only or mainly for the collection of natural resources in a common use regime. In the SNSP, where environmental relevance and the possibility of land use coexist, there was a conflict over the human occupation of the PA. In the RPSP, the ecological importance of the area is not associated with the possibility of agricultural exploration, minimizing competition over resources. Further detail about the context of the creation of both PAs and about the patterns of resources use in the area is provided in Ribeiro et al. (2018) and Ribeiro (2013). The research that originated this paper encompasses the period before the creation of the parks until the end of 2012.

\subsection{MONITORING OF SOIL COVERAGE}

Landsat 5 classified images and classification published in the Inventário Florestal... resulted in the cover percentages presented in Table 1.

Table 1 | Percentage of native floral cover in the Rio Preto and Serra Negra State Parks, 1986, 1992, 2003 , and 2009.

\begin{tabular}{|c|c|c|c|c|c|}
\hline & classifications & 1986 & 1992 & 2003 & 2009 \\
\hline \multirow{2}{*}{ RIO PRETO SP } & native landscapes & $64 \%$ & $61 \%$ & $69 \%$ & $69 \%$ \\
\cline { 2 - 6 } & cultural landscapes & $36 \%$ & $39 \%$ & $31 \%$ & $31 \%$ \\
\hline \multirow{2}{*}{ SERRA NEGRA SP } & native landscapes & $62 \%$ & $58 \%$ & $63 \%$ & $61 \%$ \\
\cline { 2 - 6 } & cultural landscapes & $38 \%$ & $42 \%$ & $37 \%$ & $39 \%$ \\
\hline
\end{tabular}


Quantification of vegetation in the RPSP shows its efficiency in maintaining native vegetation. Between 1992 and 2009, the percentage of native vegetation cover increased by about 8\%, equivalent to 3,785 hectares.

Regarding the areas classified as $\mathrm{CL}$, a methodological caveat is required. Some of these areas are actually rocky outcrops. These areas have no vegetation cover. In this text, we sought to take advantage of the official data of the Inventário Florestal..., which focused on plant species. The methodological choice was to maintain areas with rocky outcrops as CL. Considering that vegetation cover can vary in the landscape, but that this never happens in rocky outcrops, the latter have not changed over time nor appear in the monitoring as a decline of the native vegetation.

Image 3 shows landscape changes in RPSP and surrounding areas in the years under study.

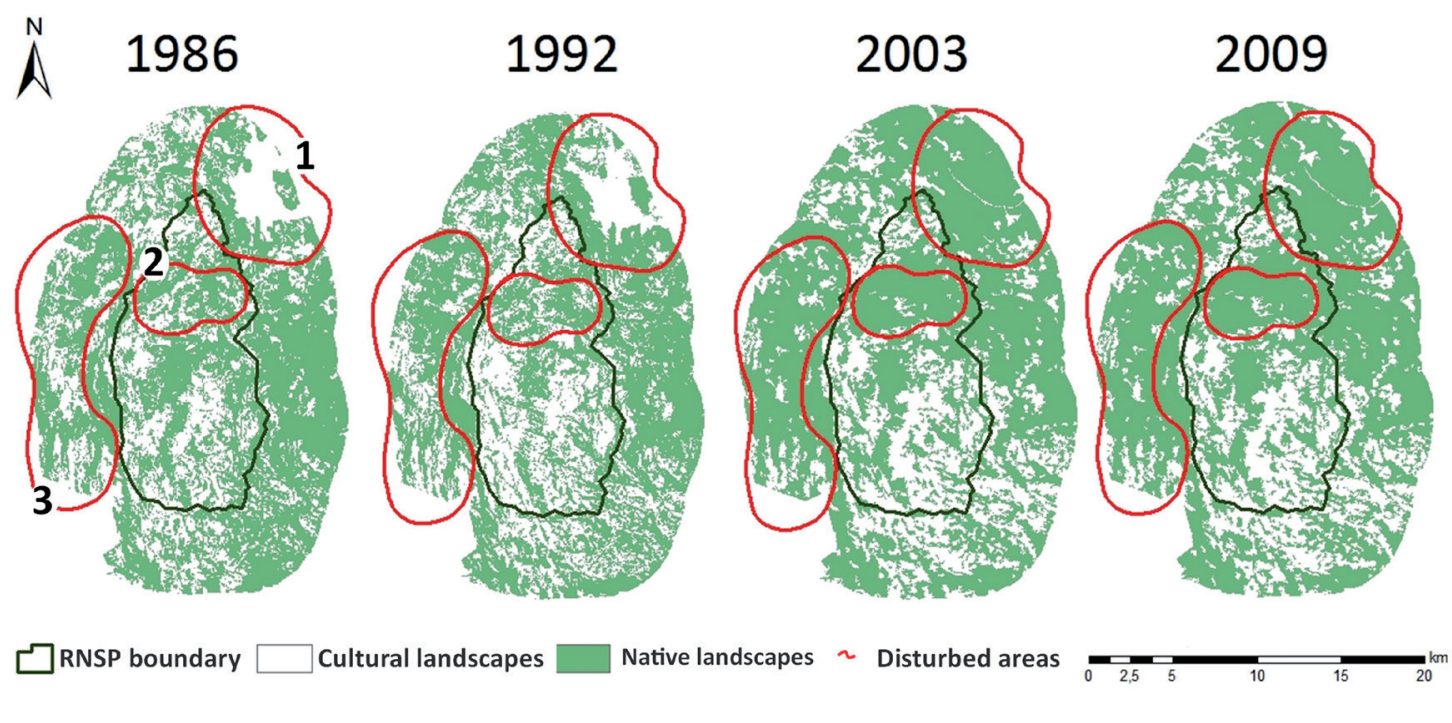

Image 3 | Soil cover changes in the Rio Preto State Park and surrounding area between 1986 and 2009. Source: IEF (2013).

The areas circled in red in Image 3 are those that had the strongest increases in native vegetation during the period under study. The area marked with the number ' 1 ' was classified as $C L$, because in the years studied (1986 and 1992) their orbital images displayed burning scars. This same encircled area is crossed by the only road in the study area. It connects downtown São Gonçalo do Rio Preto to the RPSP.

This unpaved road runs parallel to the Preto River for a few kilometers. The recovery of this area's vegetation probably resulted from the park's creation. A recurrent comment made by interviewed local residents and landowners was that inspection enforcement was strengthened after the creation of the park. Comparing pre- and post-park landscapes, this is confirmed, since area ' 1 ', in addition to being included in the management plan as a buffer zone, is characterized as $\mathrm{APP}^{3}$ (permanent preservation area), as it lies along a river (Brasil, 2012). Another possible explanation for the recovery of this area is the increase in tourism focused on the Preto River. Interviewed residents of local communities reported the arrival of people from other municipalities who buy land along the banks of the Preto River for recreational use. According to them, after the creation of the RPSP, lands closest to the river became highly valued, giving rise to opportunities for former residents to sell parts of their properties at good prices.

In Image 3, the area circled with the number ' 2 ' also experienced an increase in native vegetation. This area corresponds to the park's "intensive use" area, where campsites, visitor lodging, a restaurant 
and the visitor center are located. Before the creation of the RPSP, this area hosted charcoal kilns, a definite clue of native vegetation cutting. The campsite is located in the former corral of the Boleiras Farm. The IEF architect responsible for the park's buildings informed that its "intensive use" zone was plotted in this point in order to take advantage of areas in which the native cerrado vegetation had been significantly altered and to build facilities necessary for the PA's operation. It is remarkable that native vegetation made a comeback in this section despite previous uses and despite the RPSP itself.

Examining the circled area number ' 3 ' in Image 3, we see that it was also affected by a considerable regeneration of native vegetation. Factors mentioned in the case of the ' 1 ' area, such as stronger inspection over the opening of cultivation fields and vegetation burning, are probable reasons for regeneration in area ' 3 '. However, a factor specific to this area, which lays within the municipality of Couto de Magalhães de Minas, is the presence of another PA, the Rio Manso Área de Proteção Ambiental (environmental preservation area - APA, an official PA category). It was created by the municipal government. Although APAs allow the sustainable use of their areas, the presence of this APA may have restricted deforestation in area ' 3 '.

\subsubsection{SERRA NEGRA STATE PARK}

As shown by the data in Table 1, until 2003 the vegetation cover of the SNSP followed the same trend as the RPSP: native vegetation shrunk between 1986 and 1992 and increased between 1992 and 2003. However, in the case of the SNSP, between 2003 and 2009 the native floral cover decreased slightly, while in the RPSP it remained constant. Image 4 shows these changes.

Fluctuations in vegetation cover shown in Table 1, when superimposed on information collected in field interviews, shape a remarkable scenario. A common observation came out of the interviews conducted with the representative of the Rural Workers Union of Itamarandiba and those conducted with IEF employees (both from the local office and the central office in Belo Horizonte) about the SNSP's implementation. According to interviewees, after the park's creation (1998), there was a period of stagnation until it was set up. This stagnation lasted until 2007, when the team responsible for demarcating the unit's boundaries informed landowners that the area had become a park and that they would be expropriated soon, receiving compensation for their properties.
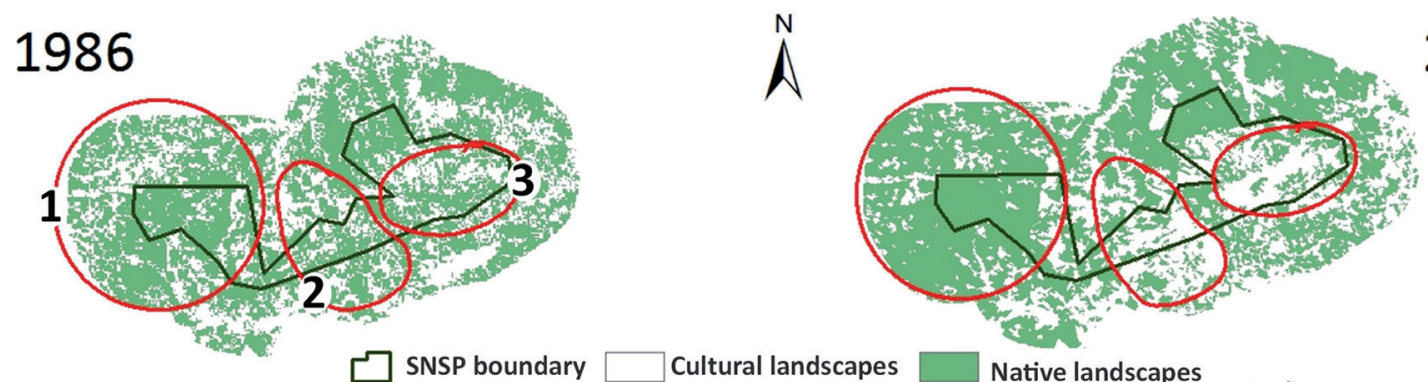

2003

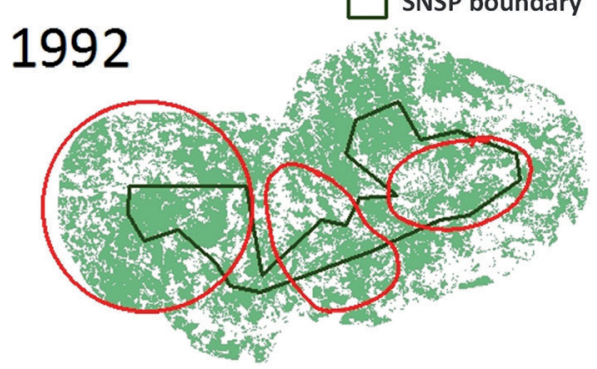

$\square$ Cultural landscapes $\square$ Native landscapes

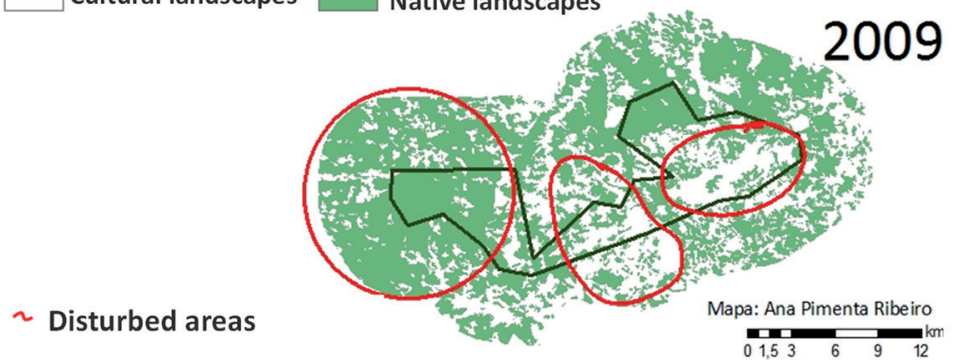

Image 4 | Soil cover changes in the Serra Negra State Park and surrounding area between 1986 and 2009.

Source: IEF, Ribeiro (2013). 
Some farmers abandoned their properties after learning this, because they believed that the compensation would follow soon. The park lies in a transition area between the Cerrado biome and the Atlantic Forest biome (the latter is protected against various types of use by Law 11.428 , of December 22, 2006). This area has available water, fertile soils and fragments of native vegetation that function as sources of seeds and propagules of native species. It also hosts the fauna that can carry out seed dispersion, which means that the recovery of native vegetation tends to happen quickly. The aforementioned law stipulates that fragments of regenerating Atlantic Forest, even if they have only non-woody pioneer species, cannot be cut (Brasil, 2006). The fact that these regenerating fragments lie within a protected area further restricts cutting, even outside the Atlantic Forest domain. As the park's implementation lingered, in 2010 farmers formed an association to request compensation or permission to start cultivating their lands again.

Comparing the history of conflicts generated by the creation of the SNSP with the history of local land use, the facts reported by interviewees and the history of landscape changes fit each other quite well. Although the percentage of the area covered by native vegetation expanded between 1992 and 2003, this period coincides in part to the lack of park implementation - the park was created in 1998. In the following period, 2003 to 2009, when the park agency officially informed the local population about the park's existence and about restrictions to the opening of new agricultural areas, the regrowth of native vegetation cover could be expected. However, this did not happen, maybe because there was no time for such a recovery to be captured by the 2009 images.

Among the areas marked in Image 4 as having gone through the strongest change in the SNSP landscape in the years under study, only the reduction of native vegetation cover in area number ' 2 ' can be associated with an impacting anthropic factor - a road. A state highway cuts through the park's narrower portion. In several cases, mainly in the Brazilian Amazon region, roads are a typical factor in the expansion of human occupation and productive activities - including deforestation (Brondizio et al., 2009; Li et al., 2019). Areas ' 1 ' and ' 3 ' correspond to the SNSP's highest altitudes.

Some hypotheses can be proposed about changes in the SNSP landscape. First hypothesis: Despite being used traditionally in landscape monitoring and having achieved relevant results in the RPSP, the methodology adopted in our research may not be adequate to capture the relationship between changes in the landscape and human actions. This may be checked by a study that uses orbital images with a higher resolution.

Second hypothesis: the population did not feel the effect of the PA and therefore the PA did not lead to changes in land uses. In other words: the effect of the park's creation was not reflected in changes in the landscape. Indeed, there was a small variation in the percentage of native vegetation cover, but this could be caused by the traditional management system of the environment employed by populations residing in the PA and its surroundings.

Third hypothesis: given the emerging effects of the growth of economies of scale in agriculture, the reduced gains from small-scale agriculture, the relative aging of the rural population, and the growth of social programs such as rural retirement and Bolsa Família, ${ }^{4}$ there could be a reduction in cultivated areas leading to the increase of areas with native landscapes, conserved "structurally" by encompassing socioeconomic circumstances.

\section{LANDSCAPE USE PROJECTIONS}

The image generated by the model for 1994 was compared to the Landsat 5 image classified for the same year. According to Pontius et al. (2004), comparison between the image generated by the model and the real classification ( $T_{2 R}$ - image of time $T_{2}$ generated from the Landsat image classification) by itself does not guarantee the validity of the model. There is no universally accepted criterion for 
assessing the validity of a land use prediction model. In this same work, the authors suggest that it is of central importance in any validation process to compare the $T_{2 R}$ image to the classified image that was the basis of the model's creation ( $T_{1 R}-$ image of time $T_{1}$ generated from Landsat classification image). The landscape generated by the model ( $T_{2 \mathrm{M}}$ - image of time $\mathrm{T}_{2}$ generated by the model) must be closer to $T 2_{R}$ than to $T_{1 R^{\prime}}$, thus justifying the use of the model. Here, $T_{1}$ was considered as the year 1992 and $T_{2}$ the year 1994 .

The result of the comparison between vegetation cover in image $T_{2 R}$ with image $T_{2 M}$ was a coincidence of $70 \%$. The null model (comparison of image $T_{2 R}$ to image $T_{1 R}$ ) resulted in a correctness of $61 \%$. In other words, the generated model made a better explanation landscape changes occurring between $\mathrm{T}_{1}$ and $\mathrm{T}_{2}$ than the null model. For the purpose of our study, the model's percentage of correctness was considered satisfactory, despite being lower than the percentages obtained by other studies that used LCM and different validation methods (see Faleiro et al., 2013).

\subsection{RIO PRETO STATE PARK}

The values of the estimated extension of native cover in the RPSP for the years 2003 and 2009 are shown in Table 2.

Table 2 | Comparison between the native vegetation cover of the official classification (Official Native Percentage - ONP) and the native vegetation cover estimated by the model (Estimated Native Percentage - ENP) applied to the Rio Preto State Park.

\begin{tabular}{|c|c|c|}
\hline & 2003 & 2009 \\
\hline NPO & $69 \%$ & $69 \%$ \\
\hline NPE & $47 \%$ & $45 \%$ \\
\hline NPO-NPE & $22 \%$ & $24 \%$ \\
\hline
\end{tabular}

Source: Ribeiro (2013).

According to the model generated for the RPSP and its surrounding area, in a scenario in which the park did not exist the native vegetation cover in the area would be around $47 \%$ in 2003 and $45 \%$ in 2009. According to the model, the existence of the park guaranteed the conservation of $24 \%$ of native vegetation cover until 2009. Image 5 shows the classifications and projections for each year. This result indicates that the PA is fulfilling its function of conserving native vegetation, because if the trend of land use prior to its creation continued, almost a quarter of the area under analysis would have been converted into a cultural landscape by 2009.

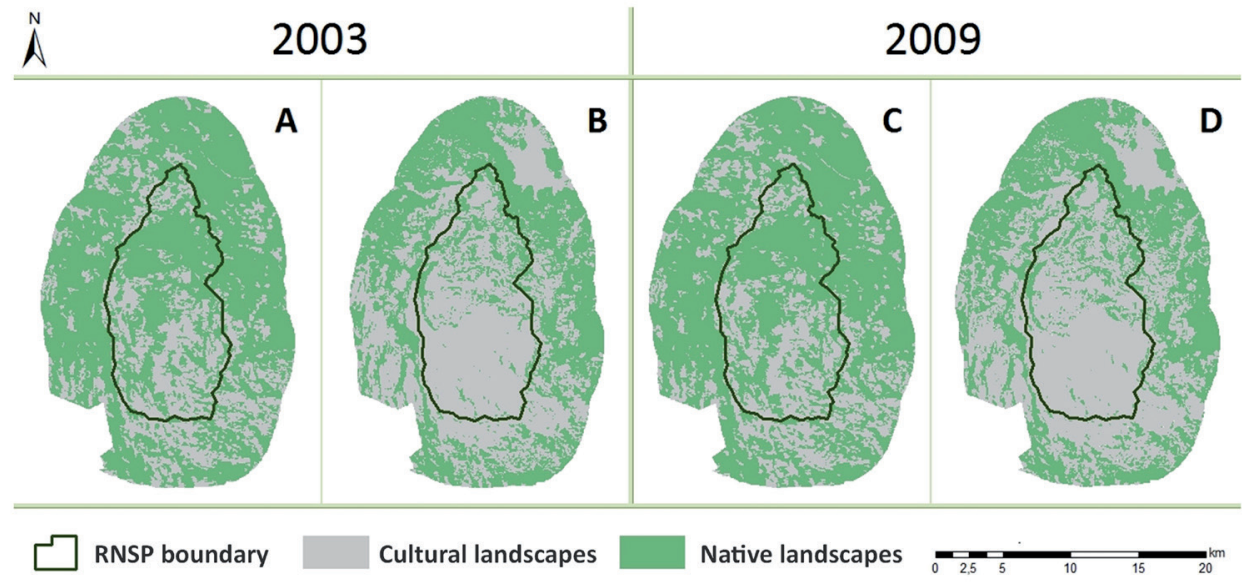

Image 5 | Comparison between landscapes obtained by the Inventário Florestal de Minas Gerais (A and C) and landscapes generated by the Land Change Modeler ( $B$ and $D)$ in the Rio Preto State Park. 
Analyzing the landscapes used in the construction of the model, there was a $3 \%$ reduction in native cover between 1986 and 1992 (Image 3). The cover projection is not computed solely on the base of this information. The other variables used in the construction of the model are also included in the determination of this future landscape.

Connecting this data to the region's history, it is clear that the conservationist trend, which emerged in the municipality of São Gonçalo do Rio Preto in the late 1980s and resulted in the creation of the PA in 1994, possibly had no direct effect - or maybe such an effect could not have been captured - on landscape changes between 1986 and 1992. The movement to protect the Preto River came about from the initiative of the urban population of the municipality of São Gonçalo do Rio Preto, but neighboring farmers did not participate in the movement for the creation of the RPSP or in the definition of its limits.

\subsection{SERRA NEGRA STATE PARK}

Native cover data estimated by the model for the SNSP is shown in Table 3.

Table 3 | Comparison between the native vegetation cover of the official classification (Official Native Percentage - ONP) and the native vegetation cover estimated by the model (Estimated Native Percentage - ENP) applied to the Serra Negra State Park.

\begin{tabular}{|c|c|c|}
\hline & 2003 & 2009 \\
\hline NPO & $63 \%$ & $61 \%$ \\
\hline NPE & $65 \%$ & $66 \%$ \\
\hline NPO-NPE & $-2 \%$ & $-5 \%$ \\
\hline
\end{tabular}

Source: Ribeiro (2013).

The images generated by the model indicated that, without the existence of the park, the landscape's native coverage would have been about 2\% greater in 2003 and 5\% greater in 2009 (Image 6). This difference is equivalent to a deficit of more than 2,700 hectares of native vegetation for the year 2009 . The result indicates that the SNSP has not been fulfilling its role of maintaining native vegetation, because the projection that does not consider the existence of the park estimated that, in its absence, there would be a more extensive native vegetation cover. Problems in the establishment of the park's boundaries, the way these limits were established, and IEF's delay in 'taking over' the park may have conditioned this result. Schleicher et al. (2019) obtained similar results, identifying lack of inspection and lack of proper land entitlement as major challenges in PA management.

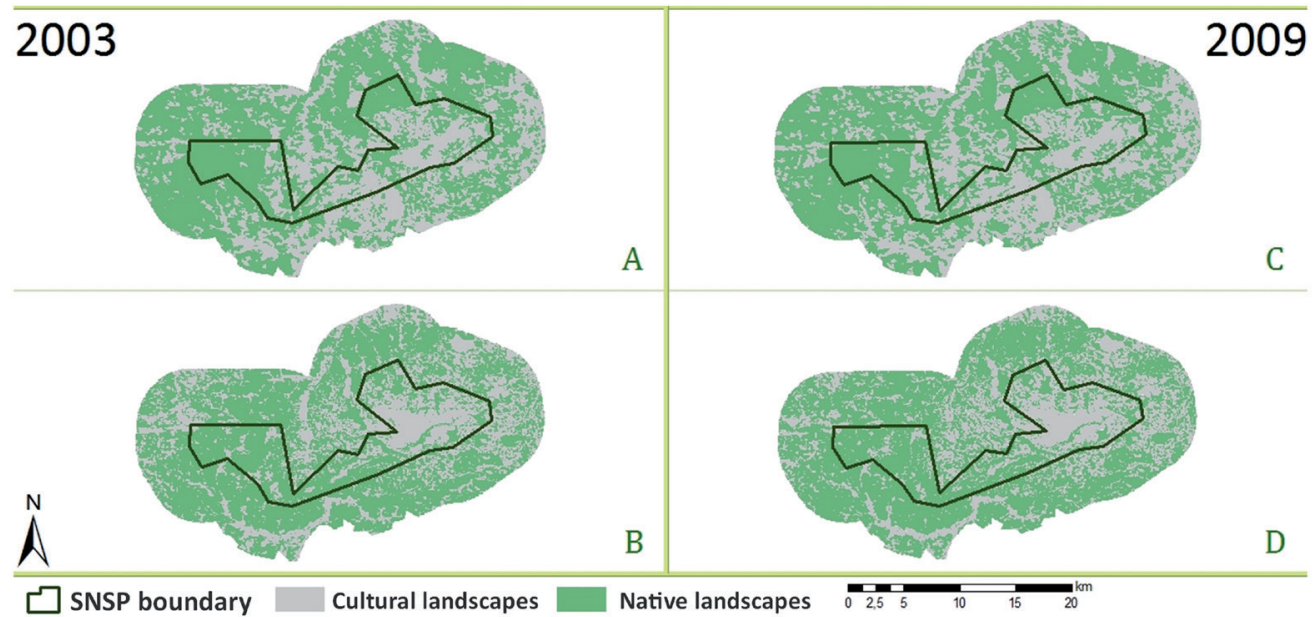

Image 6 | Comparison between landscapes obtained by Inventário Florestal de Minas Gerais (A and C) and landscapes generated by Land Change Modeler (B and D) in the Serra Negra State Park. 
Another inference emerges from this diagnosis. The magnitude of these differences, 2 and $5 \%$, shows that the land use trend between 1986 and 1992 in the RPSP, analyzed by the model, caused considerably less impact on vegetation cover when compared to the trend recorded in the SNSP. For the SNSP, the trend would lead to an increase in native vegetation, which would grow from $58 \%$ in 1992 to $65 \%$ in 2003. The model resulted in a landscape with a tendency for recovery in the years to come.

Analyzing the effectiveness of parks in conserving biodiversity in tropical regions, Bruner et al. (2001) found that the number of people residing inside the PAs did not have a positive correlation with PAs' effectiveness. Despite this finding being questioned by ecological scientific bases (Françoso et al., 2015) such as in the Cerrado, where opportunities for conservation are rapidly diminishing. We evaluate how different categories of protected areas (PAs, the authors concluded that effectiveness was strongly correlated with the number of PA employees, for example. Bruner et al. (2001) also showed that $17 \%$ of the sampled parks ( 23 years old, on average) experienced net losses in vegetation cover after the installation of the PAs. The trends identified in the SNSP are in line with these findings and those of several authors (such as Engen et al. 2018; Schleicher et al. 2019; Young et al. 2020), because the impact of the resident population inside the park was small, despite losses in native vegetation.

In the case of the SNSP, the families interviewed during our field research and their representative in the local Rural Workers Union revealed that they maintain a close connection with their environment, practicing low-impact agriculture, as reported by GALIZONI (2007). Even with the impossibility of opening new areas for cultivation and with the need to keep previously cleared land in cultivation, the trends in landscape use remained practically unchanged. Guadilla-Sáez et al. (2020) obtained results that follow the same logic, observing the effect of replacing traditional community governance in an area of common use in Spain: state intervention destabilized a management system that had worked well since the Middle Ages. Management that involves traditional communities, using local solutions, is more likely to solve conflicts around PAs (Branco et al., 2020).

Research in LUCC allows us to understand interactions between different components of the process. Brondizio et al. (2009) sustain that there is a direct link between the communities' economic / cultural / social context and the 'mark' that they leave on landscapes - in this case, the 'mark' is the product captured by the orbital images. Integrating field research with remote sensing techniques allows us to produce an explanation of the whole that would not be possible if only one of the two 'techniques' were to be applied separately. This allows for a deeper and more complex understanding of the processes that communities go through and the specific needs of each one of them. However, on their own, data about LUCC do not help understand the processes and causes of changes (Lambin et al., 2001).

\section{FINAL REMARKS}

Landscape changes in the period under study, inferred from images and their treatment, corroborated field studies that have found an increase in the population's perception of environmental problems and more severe direct control over deforestation and fires in the municipality of São Gonçalo do Rio Preto after the creation of the RPSP (Ribeiro et al., 2018). As for the SNSP, few relationships were found. This may be due to the scale used in our research. A major challenge is to integrate the local view scale characteristic of field-based social science studies - with a more regional and global view, commonly used in the ecological and biophysical sciences. The strength of studies about land use change lies in the ability to integrate different areas of knowledge and their different theoretical and methodological approaches.

If, on the one hand, modeling results indicated the effectiveness of the RPSP in the conservation of local native vegetation, on the other hand there was also evidence that the pre-existing local trend of degradation of natural resources was changed after the PA's installation. One factor that may have influenced the identification of this trend was the failure to identify the rocky outcrops (that we classified as $\mathrm{CL}$ ) and that the model understood as a product of human action, thus reinforcing the 
alteration trend. A new classification that includes the detailed identification of outcrops must be made to test whether their size and their representativeness in the landscape really change the projections.

A future analysis that can complement the present study is the construction of models that (i) isolate PA areas from their surroundings and (ii) use more recent data that allow capturing the context. Quantifying and understanding trends and checking for differences in this area can improve the model and bring valuable information for understanding interactions between local populations and their natural environments.

The research that generated these results was funded by Brazil's CNPq Foundation (Conselho Nacional de Pesquisas) and by the European Union, through the FP7 - 2010, under accord \#O SSH-CT-2010-266710.

\section{NOTES}

1 I CNPq Foundation (Brazil' National Research Council) A previous version was presented at the conference entitled "VI Seminário Brasileiro and I Encontro Latino-Americano Sobre Áreas Protegidas e Inclusão Social" (Belo Horizonte - Brazil, September 2013). A summary was presented at the IALE European Congress 2017" (Ghent - Belgium). The annals of both events published this previous version.

2 | The years that demarcate the intervals are 1986, 1992, 2003 e 2009.

3 | INPE is the Instituto Nacional de Pesquisas Espaciais, Brazil's federal agency in charge of space science. Then selected images were obtained at http://www.dgi.inpe.br/CDSR/

3 | Further information available at http://goo.gl/s5Tla

4 | Ability of the variable to explain the occurrence of land use change.

5 | Brazilian forest use legislation defines several types of "APPs" to be found - and preserved - inside in all private and public rural properties. Swaths along rivers banks are one of these types; hilltops, steep slopes, lake borders, mesa edges and mangroves are some of the other types.

6 | Bolsa Familia is an income transfer program created by the federal government in 2004. It targets Brazilians who have the lowest levels of family per capita income. Currently the program benefits more than 11 million families.

\section{REFERENCES}

ALMG. Notas taquigráficas da 28a Reunião Ordinária da Comissão de Direitos Humanos, 2010.

BRANCO, P.S., MERKLE, J.A., PRINGLE, R.M., KING, L., TINDALL, T., STALMANS, M., LONG, R.A. An experimental test of community-based strategies for mitigating human-wildlife conflict around protected areas. Conserv. Lett. 13. https://doi.org/10.1111/conl.12679, 2020.

BRASIL, LEI No 12.651, DE 25 DE MAIO DE 2012.

BRASIL, Lei no 11.428, DE 22 DE DEZEMBRO DE 2006. Dispõe sobre a utilização e proteção da vegetação nativa do Bioma Mata Atlântica, e dá outras providências, 2006.

BRASIL, LEI No 9.985, DE 18 DE JULHO DE 2000. Art. 2o, paragrafo XVIII, 2000.

BRONDIZIO, E.S., OSTROM, E., YOUNG, O.R., 2009. Connectivity and the Governance of Multilevel SocialEcological Systems: The Role of Social Capital. Annu. Rev. Environ. Resour. 34, 253-278. https://doi.org/10.1146/ annurev.environ.020708.100707, 2009

BRUGGER, S.O., GOBET, E., VAN LEEUWEN, J.F.N., LEDRU, M.-P., COLOMBAROLI, D., VAN DER KNAAP, W.O., LOMBARDO, U., ESCOBAR-TORREZ, K., FINSINGER, W., RODRIGUES, L., GIESCHE, A., ZARATE, M., VEIT, H., TINNER, W. Long-term man-environment interactions in the Bolivian Amazon: 8000 years of vegetation dynamics. Quat. Sci. Rev. 132, 114-128. https://doi.org/10.1016/J.QUASCIREV.2015.11.001, 2016. 
BRUNER, A.G., GULLISON, R.E., RICE, R.E., DA FONSECA, G.A.B. Effectiveness of parks in protecting tropical biodiversity. Science (80-. ). 291, 125-128. https://doi.org/10.1126/science.291.5501.125, 2001.

CARRANZA, T., MANICA, A., KAPOS, V., BALMFORD, A. Mismatches between conservation outcomes and management evaluation in protected areas: A case study in the Brazilian Cerrado. Biol. Conserv. 173, $10-16$. https://doi.org/10.1016/J.BIOCON.2014.03.004, 2014

CORRÊA, R.L. A dimensão cultural do espaço: alguns temas. Espaço e Cult. 1-22, 1995.

EASTMAN, J.R. IDRISI Selva, 2012.

ENGEN, S., RUNGE, C., BROWN, G., FAUCHALD, P., NILSEN, L., HAUSNER, V. Assessing local acceptance of protected area management using public participation GIS (PPGIS). J. Nat. Conserv. 27-34, 2018.

FALEIRO, F. V., MACHADO, R.B., LOYOLA, R.D. Defining spatial conservation priorities in the face of land-use and climate change. Biol. Conserv. 158, 248-257. https://doi.org/10.1016/j.biocon.2012.09.020, 2013.

FERRAZ, S.F. DE B., VETTORAZZI, C.A., THEOBALD, D.M. Using indicators of deforestation and land-use dynamics to support conservation strategies: A case study of central Rondônia, Brazil. For. Ecol. Manage. 257, 1586-1595. https://doi.org/10.1016/J.FORECO.2009.01.013, 2009.

FRANÇOSO, R.D., BRANDÃO, R., NOGUEIRA, C.C., SALMONA, Y.B., MACHADO, R.B., COLLI, G.R. Habitat loss and the effectiveness of protected areas in the Cerrado Biodiversity Hotspot. Nat. Conserv. 13, 35-40. https://doi. org/10.1016/J.NCON.2015.04.001, 2015.

GALIZONI, F.M. A terra construída: família, trabalho e ambiente no Alto do Jequitinhonha, Minas Gerais. Editora do Banco do Nordeste, Fortaleza, 2000.

GUADILLA-SÁEZ, S., PARDO-DE-SANTAYANA, M., REYES-GARCÍA, V. Forest commons, traditional community ownership and ecological consequences: Insights from Spain. For. Policy Econ. 112, 102107. https://doi. org/10.1016/J.FORPOL.2020.102107, 2020.

HERINGER, G., ALMEIDA, T.E., DITTRICH, V.A. DE O., SALINO, A. Assessing the effectiveness of protected areas for the conservation of ferns and lycophytes in the Brazilian state of Minas Gerais. J. Nat. Conserv. 53, 125775. https://doi.org/10.1016/J.JNC.2019.125775, 2020.

INSTITUTO CHICO MENDES. Conama aprova regulamentação de zona de amortecimento de unidades de conservação [WWW Document]. Portal Bras. URL http://goo.gl/UyhYW (accessed 12.30.12), 2010.

KUGLER, T.A., GRACE, K., WRATHALL, D.J., DE SHERBININ, A., VAN RIPER, D., AUBRECHT, C., COMER, D., ADAMO, S.B., CERVONE, G., ENGSTROM, R., HULTQUIST, C., GAUGHAN, A.E., LINARD, C., MORAN, E., STEVENS, F., TATEM, A.J., TELLMAN, B., VAN DEN HOEK, J. People and Pixels $\mathbf{2 0}$ years later: the current data landscape and research trends blending population and environmental data. Popul. Environ. 41, 209-234. https://doi.org/10.1007/ s11111-019-00326-5, 2019.

LAMBIN, E.F., TURNER, B.L.L., GEIST, H.J., AGBOLA, S.B., ANGELSEN, A., BRUCE, J.W., COOMES, O.T., DIRZO, R., FISCHER, G., FOLKE, C., GEORGE, P.S.S., HOMEWOOD, K., IMBERNON, J., LEEMANS, R., LI, X., MORAN, E.F., MORTIMORE, M., RAMAKRISHNAN, P.S.S., RICHARDS, J.F., SKÅNES, H., STEFFEN, W., STONE, G.D., SVEDIN, U., VELDKAMP, T.A., VOGEL, C., XU, J., BRUCE, J.W., COOMES, O.T., DIRZO, R., GEORGE, P.S.S., HOMEWOOD, K., IMBERNON, J., LEEMANS, R., LI, X., MORAN, E.F., MORTIMORE, M., RAMAKRISHNAN, P.S.S., RICHARDS, J.F., STEFFEN, W., STONE, G.D., SVEDIN, U., VELDKAMP, T.A. The causes of land-use and land-cover change: moving beyond the myths. Glob. Environ. Chang. 11, 261-269. https://doi.org/10.1016/S0959-3780(01)00007-3, 2001.

LI, G., LU, D., MORAN, E., CALVI, M.F., DUTRA, L.V., BATISTELLA, M. Examining deforestation and agropasture dynamics along the Brazilian TransAmazon Highway using multitemporal Landsat imagery. GIScience Remote Sens. 56, 161-183. https://doi.org/10.1080/15481603.2018.1497438, 2019.

MORAN, E.F. O desafio de pesquisa em interações homem-ambiente, in: Moran, E.F. (Ed.), Meio Ambiente e Ciências Sociais: Interação Homem-Ambiente e Sustentabilidade. Senac, São Paulo, pp. 21-50, 2011. 
PONTIUS, R.G., HUFFAKER, D., DENMAN, K., GILMORE, R., JR, P. Useful techniques of validation for spatially explicit land-change models. Ecol. Modell. 179, 445-461. https://doi.org/10.1016/j.ecolmodel.2004.05.010, 2004.

PREFEITURA MUNICIPAL DE ITAMARANDIBA. Itamarandiba MG [WWW Document]. URL http://www. itamarandiba.mg.gov.br (accessed 10.18.12), 2012.

RIBEIRO, A.P. A caligrafia da sociedade na paisagem Transformações no entorno de unidades de conservação da Serra do Espinhaço - MG. Universidade de Brasília - UnB. https://doi.org/10.13140/2.1.4897.4726, 2013.

RIBEIRO, A.P., DRUMMOND, J.A., RIBEIRO, E.M., CALDAS, A.L. OS PARQUES E SEUS ENTORNOS: DOIS ESTUDOS DE CASO NO VALE DO JEQUITINHONHA MINEIRO, in: XXI Encontro Nacional de Estudos Populacionais. Poços de Caldas - MG. https://doi.org/978-85-85543-32-7, 2018.

RIBEIRO, E.M., GALIZONI, F.M., CALIXTO, J.S., ASSIS, T.D.P., AYRES, E.B., SILVESTRE, L.H. Gestão, uso e conservação de recursos naturais em comunidades rurais do Alto Jequitinhonha. Rev. Bras. Estud. Urbanos e Reg. 7, 77. https://doi.org/10.22296/2317-1529.2005v7n2p77, 2005.

SCHLEICHER, J., PERES, C.A., LEADER-WILLIAMS, N. Conservation performance of tropical protected areas: How important is management? Conserv. Lett. 12. https://doi.org/10.1111/conl.12650, 2019.

SCHULZE, K., KNIGHTS, K., COAD, L., GELDMANN, J., LEVERINGTON, F., EASSOM, A., MARR, M., BUTCHART, S.H.M., HOCKINGS, M., BURGESS, N.D. An assessment of threats to terrestrial protected areas. Conserv. Lett. 11, e12435. https://doi.org/10.1111/conl.12435, 2018.

SCOLFORO, J.R., CARVALHO, L.M.T. Mapeamento da Inventario Flora Nativa e dos Reflorestamentos de Minas Gerais. Ed. UFLA, Lavras, Minas Gerais, 2006.

SEMAD. Plano de Manejo do Parque Estadual do Rio Preto. Curitiba, 2004.

SILVA, R.F.B. DA, BATISTELLA, M., MORAN, E.F. Drivers of land change: Human-environment interactions and the Atlantic forest transition in the Paraíba Valley, Brazil. Land use policy 58, 133-144. https://doi.org/10.1016/J. LANDUSEPOL.2016.07.021, 2016.

SILVEIRA, F.A.O., FERREIRA, M.C., PERILLO, L.N., CARMO, F.F., NEVES, F.S. Brazil's protected areas under threat. Science 361, 459. https://doi.org/10.1126/science.aau4222, 2018.

TUCKER, C.M., OSTROM, E. Pesquisa multidisciplinar relacionando instituições e transformações florestais, in: Moran, E.F., Ostrom, E. (Eds.), Ecossistemas Florestais - Interação Homem-Ambiente. Senac, São Paulo, pp. 109-138, 2009.

YOUNG, N.E., EVANGELISTA, P.H., MENGITSU, T., LEISZ, S. Twenty-three years of forest cover change in protected areas under different governance strategies: A case study from Ethiopia's southern highlands. Land use policy 91, 104426. https://doi.org/10.1016/J.LANDUSEPOL.2019.104426, 2020. 